\title{
TEORI INVISIBLE HAND ADAM SMITH DALAM PERSPEKTIF EKONOMI ISLAM
}

\author{
Rustam Dahar KAH ${ }^{1}$
}

\begin{abstract}
Adam Smith as the founder of modern economics laid the basic foundation for economic development through the capitalist system in which capital factor used as a measuring tool for economic success. One opinion of Adam Smith "the theory of invivisble hand" in economic activity every individual has the full authority of his property and free use of economic resources in ways that he likes, disregarding the interests of the general public. This shows that capitalism has the right to have a peribadi an unlimited of the means of production, which is the driving force personal profit. Islam is essentially bringing the teachings to human life that comes the Koran and Hadith. Economic activity in the view of Islam is the guidance of life, in addition it is also a suggestion that has a dimension of worship. Wealth (material wealth) is trustworthy, thus the mandate that God bestowed it must be used together, not to suck other people or enslave other people. Islam allows every person to own property in person, but as it also enjoins on his property was to be used collectively (together), alms or spend a portion of such property in Allah. Economic activity in the view of Islam is not only material but more than that - "material plus" -. Islam has always stressed that every person living in a lawful manner. Islam also does not prohibit untukmelakukan economic activity, but Islam provides guidance and guidance in the form of Islamic values.
\end{abstract}

Keywords : Invisible hand, Ekonomi Islam, Adam Smith, kapitalisme

\section{PENDAHULUAN}

Dewasa ini ilmu ekonomi yang dikembangkan oleh sebagian besar negara, lebih di dasarkan pada apa yang disebut sebagai metode ilmiah. Ilmu ekonomi dipandang sebagai proses intelektual dan aktivitas pengelolaan yang menghasilkan konsep-konsep di derivikasi melalui pendekatan emperistik yang deduktif maupun induktif cenderung memberikan keketatan ilmiah pada disiplin ilmunya dengan menitik beratkan pada aspek-aspek positivisme dan mengabaikan nilai normatifnya. Dimana model dan teorinya selalu didasarkan pada sistem nilai tertentu. Padahal ilmu ekonomi merupakan ilmu sosial yang tidak bisa lepas dari aspek normatif.

Sejak revolusi Adam Smith dengan "teori tangan gaib" (the theory of invisible hand), ekonomi mengalami goncangan yang dasyat bagi kemajuan ilmu pengetahuan. Adam Smith pendiri madhab klasik selalu mengedepankan faktor kapital untuk mengukur keberhasilan perekonomian. Sehingga madhab ini sering disebut kapitalisme. Sesuai doktrinnya "Laissez Faire" Adam Smith berpendapat setiap individu mempunyai kuasa penuh terhadap hartanya

\footnotetext{
${ }^{1}$ Dosen Fakultas Syari’ah IAIN Walisongo Semarang.

E-mail :rustamdahar@gmail.com
} 
dan bebas menggunakan sumber-sumber ekonomi menurut cara-cara yang dikehendakinya. ${ }^{2}$ Apabila ia mempunyai satu tujuan yang memperoleh kepuasan yang sebesar-besarnya dari sumber keuangan yang tersedia, dalam hal ini individu menganut prinsip "rasionalitas ekonomi". ${ }^{3}$ Tindakan ekonomi kapitalistik Adam Smith merupakan suatu tindakan yang mempunyai kemungkinan-kemungkinan untuk mendapatkan keuntungan secara damai, karena dia melihat usaha kapitalistik yang berdasarkan mencari keuntungan secara rasional

Kapitalisme merupakan sistem ekonomi yang lebih mementingkan hak individu dan mengesampingkan kepentingan masyarakat umum. Dalam sistem kapitalisme mengandung unsur pokok yang mendominasi motivasi bekerjanya dengan perolehan, persaingan dan rasionalitas ${ }^{4}$. Perolehan maksudnya disini selalu diukur menurut ukuran uang. Perlaku ekonomi bersifat individual dengan bebas untuk mengusahakan keberhasilan ekonomi dengan cara apa saja yang dikehendakinya dan menanggung resiko peribadi. Seperti semboyan kapitalis "segala sesuatu untuk diri sendiri, peduli apa dengan orang lain". Ini menunjukkan bahwa kapitalisme mempunyai hak memiliki secara peribadi yang tidak terbatas atas alat-alat produksi, yang tenaga penggeraknya adalah laba pribadi. Sedangkan ekonomi sosialis mendahulukan kepentingan orang banyak. Atas dasar inilah sistem ekonomi tidak mengakui hak-hak individu bagi alatpalat produksi, sebgaimana juga tidak mengakui adanya kemerdekaan ekonomi individu dan menggantikan keduanya dengan hak milik umum dan kemerdekaan orang banyak. ${ }^{5}$

Dalam perspektif Islam, setiap manusia mengemban amanat dari Allah SWT. Harta benda itu merupakan amanat. Dengan demikian amanat yang dianugerahkan Allah itu hendaklah dimanfaatkan bersama, tidak untuk mengisap orang lain atau memperhamba orang lain. Islam memperkenankan setiap orang untuk memiliki harta benda secara pribadi, akan tetapi seiring itu pula Islam menuntut terhadap harta bendanya itu untuk dimanfaatkan secara kolektif (bersama), seperti dengan cara mengeluarkan zakat, infak, sedekahnya atau membelanjakan sebagian dari harta tersebut dijalan Allah. Islam juga tidak melarang untuk berbisnis, namun Islam memberikan panduan dan tuntunan berupa nilai-nilai Islami dalam berbisnis tersebut. Untuk itu amat menarik untuk dikaji bagaimana tinjauan Islam terhadap "the theory invisible hand" Adam Smith.

\section{TELAAH TEORITIS}

Kaum Merkantilis (merkantilists) merupakan pelopor pembuka pintu zaman, bagi perubahan besar pada suatu perekonomian. Ditemukan daerah-daerah baru menandai lahirnya suatu masa perniagaan yang luas dan ramai serta lahirnya negara-negara yang berdaulat. Negara-negara jajahan, dominion dan protekorat disamping negara boneka yang menjadi "tempat" untuk berkembangnya perniagaan dan perdagangan. ${ }^{6}$ Sebelumnya para filosofis agama selalu menekankan kepada jemaahnya untk membina dasar moral yang baik bagi

2 .Alfred W. Stonier, Douglass C. Hague, Teori Ekonomi, Ghalia Indonesia, Jakarta, 1984, hal 73 .

${ }^{3}$ Rasionalitas ekonomi menafsirkan perilaku manusia sebagai suatu yang dilandasi dengan perhitungan cermat, yang diarahlan dengan pandangan ke depan dan persiapan terhadap keberhasilan ekonomi. Keberhasilan ekonomi diartikan sebagai "membuat uang" dari manusia, untuk memperoleh harta, baik dalam pengertian uang maupun komoditi, merupakan tujuan hidup yang terakhir dan merupakan tonggak keberhasilan ekonomi.

${ }_{4}$ M.Abdul Mannan, Teori dan Praktek Ekonomi Islam, Terj. M.Nastangin, Dana Bakti Wakaf, Yogyakarta, 1995, hal. 311 hal 183.

5 Kaelany, Islam dan Aspek-Aspek Kemasyarakatan, Bumi Aksara, Jakarta, 1992, Cet I,

${ }^{6}$ Suherman Rosidi, Pengantar Teori Ekonomi, PT. Raja Grafindo Persada, Jakarta, 1995, hal 13. 
kehidupan ekonomi. Sampai abad XV kesehatan jiwa serta kebutuhan masyarakat secara keseluruhan dipandang sebagai hal yang lebih penting daripada kehidupan ekonomi. Mencari kekayaan duniawi untuk diri sendiri dinilai dosa, karena hal itu dapat melalaikan orang dari kesehatan jiwanya, sedangkan perekonomian pasar menghendaki sebaliknya. Keberhasilan seseorang dapat dinilai dari kemampuannya menaklukkan pesaing-pesaingnya. Orang dipandang berhasil dalam hidupnya bila mereka berhasil memperoleh kekayaan materiil daripada kekayaan moral. Lalu mulailah mereka meragukan ajaran-ajaran pendeta mereka. ${ }^{7}$ Sehingga tumbanglah kekuasaan gereja di dalam perekonomian setelah mengalami kejayaan pada berabad-abad lamanya.

Sejak jaman itu muncullah pemikir-pemikir baru perekonomian, diantaranya Adam Smith yang digelari sebagai Founder of New Economics. Perjalanan ilmu ekonomi mengalami Revolusi, sejak diterbitkan buku oleh Adam Smith yang berjudul An Inquiry into the Nature and Causes of the Wealth of Nation yang dikena dengan teori tangan gaib " the theori invible hand". Dalam buku ini pertama kali muncul perumusan tetang perekonomian kapitalisme. Adam Smith mendasarkan pada bukunya suatu sistem kebebasan alami (a system of natural liberty) dimana setiap dipersilahkan mengejar kepentingannya masing-masing. ${ }^{8}$

Menurut Adam Smith kepentingan pribadi (self interest) merupakan kekuatan pengendali perekonomian. Semua proses yang dijalankan akan menuju kearah kemakmuran bangsa, seolah-olah setiap individu didorong oleh "tangan gaib" (the invisible hand) yang mendorong mereka maju. ${ }^{9}$ Dalam bukunya The Wealth on Nation, Adam Smith menyatakan:

"Every individual endeavors to employ his capital so that its produce may be of greatest value. He generally neither intends to promote the public interest nor knows how much he is promoting it. He intends only his own security, only his own gain. And he is inthis led by an Invisible Hand to promote an end which was no part of his own intention. By pursuing his own interest he frequently promotes that of society more effectually then when be really inteds to promote it "

Setiap individu berusaha untuk menggunakan modalnya sehingga diperoleh hasil yang setingi-tingginya. Dia pada umumnya tiaklah bermaksud untuk menunjang kepentingan umum dengan perbuatannya itu, dan pula ia tidak tahu sampai seberapa jauhkan penunjangnya itu. Ia berbuat itu hanyalah untuk kepentingan sendiri, hanya untuk keuntungannya sendiri. Didalam hal ini ia dibimbing oleh suatu "Tangan Gaib" untuk mencapai sesuatu yang menjadi tujuan utamanya. Dengan mengejar kepentinga pribadi seperti itu, ia akan mendorong kemajuan masyarakat dengan dorongan yang seringkali bahkan lebih efektif daripada kalau ia memang sengaja melakukannya.

Pendapat Adam Smith tentang Invisible Hand sebenarnya sudah tua sekali umurnya, bukan saja sejak jamannya Francois Quesney, tetapi bahkan sejak zaman hidupnya Jean Baptise Colbert pemuka kaum merkantilis. Laizzes Faire dipakai sebagai pedoman pokok kaum liberal (pengikut Adam Smith), serta menjadi motto kaum kapitalis. ${ }^{10}$ Sejak revolusi Adam Smith inilah perekonomian kapitalis mengalangi jaman keemasan.

Ekonomi kapitalis yang mulai dikenal pada abad 18 yang dipopulerkan Adam Smith oleh Milton Spencer didefinisikan sebagai sebuah sistem ekonomi yang bercirikan hak milik privat atas lat-alat produksi distribusi dan pemanfaatannya untuk mencapai laba

\footnotetext{
${ }^{7}$ Daniel R. Fusfeld, The Age of the Economist, Ideas that Shape the Way we Live, Pyramid Publication, New York, 1972, hal 18

${ }^{8}$ Suherman op. cit hal. 16.

9 Paul A. Samuelson, Economics, Ninth Edition, Mc Graw Hill Kogakusha, Ltd. Tokyo, 1973, hal 3.

${ }^{10}$ Suherman Rosidi, loc.cit, hal. 16.
} 
dalam kondisi yang kompotitif. ${ }^{11}$ Menurut Max Weber, kapitalisme identik dengan pengejaran keuntungan, dan selamanya dapat diperbarui (berulang-ulang) dengan usaha kapitalistik dan rasional. Yaitu suatu tindakan yang didasarkan pada harapan terhadap keuntungan dengan memanfaatkan kesempatan-kesempatan transaksi. ${ }^{12}$

Pokok pikiran Adam Smith, tujuan utama menegakkan ilmu ekonomi adalah pembangunan masyarakat melalui pembangunan ekonomi. Kaum kapitalis berpendapat bahwa kaum pemilik modal (capital) adalah tokoh sentral dalam pembangunan ekonomi. Jika para pemilik modal (kaum kapital) dibebaskan berusaha maka usahanya itu dengan sendirinya akan memberi manfaat ke pada masyarakat sekitarnya. ${ }^{13}$ Buah pikiran Maltus (pengikut Adam Smith) berkembang kemana-mana, terutama di Amerika Serikat. Amerika Serikat menggunakan metode pembangunan ekonomi liberal ciptaan Adam Smith menurut resep Maltus. Para pemilik modal berlomba-lomba mendirikan perusahaan mempekerjakan masyarakat banyak pada akhirnya negeri ini mengalami kemakmuran.

Sedangkan menurut Karl Marx, sistem kapitalisme di Ingris abad ke 19 yang melahirkan kisah-kisah tentang kesengsaraan hidup ${ }^{14}$, adalah merupakan sistem penindasan melalui mekanisme pasar, dimana kaum pekerja terpaksa menerima upah rendah karena tidak seimbangnya antara lapangan pekerjaan dan pencari kerja, yaitu bahwa jumlah pencari kerja jauh lebih besar dibanding dengan lapangan pekerjaan yang tersedia. Dalam konteks ini para pemegang ekonomi kapitalis memanfaatkan kesempatan dengan cara penindasan tersebut. Permasalahan seperti inilah yang memicu para kaum kapitalis dapat mengembangkan sistem ekonomi kapitalisme di negara-negara berkembang dengan cara mengambil keuntungan yang luar biasa. Sebagai dampak dari sistem ini maka negara-negara berkembang tidak bisa menjadi maju, sebaliknya negara-negara maju terus menjadi negara maju.

Kemudian G.G. Wells berpendapat bahwa kapitalisme adalah sesuatu yang tidak dapat didefinisikan, tetapi pada umumnya sering disebut sebagai sistem kapitalis, merupakan kebiasaan tradisional, energi perolehan tidak terkendalikan, kesempatan jahat dan pemborosan hidup. ${ }^{15}$

Konsep kapitalisme menurut Sombart sebagai dasar sisitem pemikiran ekonomi, konsep ini menunjukkan bahwa kapitalisme adalah suatu sistem yang secara jelas ditandai oleh berkuasanya "kapital". Seperti sistem ekonomi lainnya, kapitalisme juga mengandung unsur pokok yang yang merupakan semangat atau pandangan ekonomi-jumlah dari keseluruhan tujuan, motif dan prinsip ${ }^{16}$. Adapun ciri-ciri kapitalisme, yaitu:

Pertama, tidak ada perencanaan. Dalam sistem ekonomi kapitalisme tidak ada rencana ekonomi senteral. Tindakan ekonomi yang tidak terkoordinasi dan bersifat individual yang bebas. Ketika kondisi bersaing merupakan kekuatan pasar, tidak adanya rencana ekonomi

${ }^{11}$ Winardi, Kapitalisme Versus Sosialisme, Suatu Analisis Ekonomi Teoritis, Remadja Rosdakarya, Bandung, 1986, Cet. I, hal 33

${ }^{12}$ Max Weber, Kapitalisme, Demokrasi dan Agama, Terj. Hartono H., Tiara Wacana Yogyakarta, 1989, hal. 20

13 Pikiran Maltus, jika sebuah pabrik didirikan misalnya, maka pabrik itu mengambil penduduk sekitarnya sebagai tenaga kerja, akan dibangunnya pula jalan, didirikan sekolah, tempat ibadah, rumah sakit dan sebagainya. Semakin besar pabrik atau perusahaan semakin makmur penduduk sekitarnya. Jika semua perusahaan dibiarkan maju maka, mau tidak mau, penduduk secara keseluruhan akan mendapatkan manfaat daripadanya, dan makmurlah seluruh negeri.

${ }^{14}$ Pengusaha (kaum kapital) yang sudah makmur masih ingin bertambah kemakmurannya. Dengan segala cara diuasakannya ada tambahan keuntungan. Yang paling populer waktu itu pengambilan tenaga kerja wanita dan anak-anak sebagai pekerja, karena upahnya lebih rendah dari tenaga kerja pria. Akhirnya tenaga kerja pria banyak yang di berhentikan diganti dengan tenaga wanita dan anak-anak. Akibatnya terjadi penindasan kaum buruh, pengangguran besar-besaran , merajalelanya kemiskinan dimana-mana akibat ulah kaum kapitalis, yang pada akhirnya menyengsarakan rakyat

${ }^{15}$ M. Abdul Mannan, Op.Cit., hal. 311.

16 , Ibid., hal. 312 
bukan alasan "laissez faire”. Laissez faire, adalah suatu ungkapan yang arti praktisnya prinsip pasar bebas. Jeremy Benthan berasumsi bahwa laissez faire (pasar bebas) adalah the greatest happines for the greatest number, maksudnya untuk menghasilkan kebahagiaan sebesar-besarnya bagi sebanyak-banyak orang. Asumsi ini mengandung optomisme dalam ideologi kapitalisme, prinsip tersebut dianggap sebagai kepercayaan. Maka para pengkritik kapitalisme menganggap laissez faire adalah suatu dogma atau semacam mitos dalam ekonomi. ${ }^{17}$

Kedua, kekuasaan konsumen.Tidak adanya suatu rencana ekonomi senteral mengandung arti bahwa adanya kekuasaan para konsumen dalam ekonomi kapitalis. Namun bukanlah kapitalisme dianggap sebagai sistem demokrasi sepenuhnya dari para konsumen. Sesungguhnya kapitalisme mengandung arti kedaulatan bagi produsen.

Ketiga, kebebasan Memilih Pekerjaan. Maksudnya bahwa untuk menarik suplai dari suatu jenis khusus tenaga kerja yang mencukupi pada suatu industri, dimana tenaga kerja lebih dibutuhkan dimana saja, maka pemberian upah harus cukup tinggi agar mempunyai daya tarik, maka hal seperti itu bertentangan dengan distribusi pendapatan yang merata. Karl Marx mengemukakan bahwa pekerja dalam sistem kapitalis adalah "bebas dalam arti ganda, pertama sebagai manusia bebas, ia dapat memberikan tenaga kerjanya sebagai komiditinya sendiri, kedua ia tidak dapat mempunyai komiditi lain untuk dijual, dan iapun tidak mempunyai segala sesuatu yang diperlukan untuk merealisasikan tenaga kerjanya". ${ }^{18}$ Atas dasar itu seorang pekerja yang menerima gaji rendah maka dia akan bebas memilih pekerjaan.

Keempat, kebebasan Berusaha. Dalam sistem kapitalisme kebebasan diartikan sebagai kemerdekaan untuk memperoleh hak milik, karena hak milik diperlukan untuk pemeliharaan kemerdekaan pribadi.

Kelima, kebebasan untuk Menabung dan Menginvestasi. Dalam kapitalisme, kebebasan menabung didukung dan ditingkatkan oleh hak untuk mewariskan kekayaan. Dalam ekonomi kapitalis pengusaha mengambil keuntungan dari kesempatan investasi dengan menggunakan dana yang dihimpun dari para penabung perorangan demi menawarkan bunga untuk membayar bunga dari hasil investasi mereka, maka dengan cara demikian maka terbentuklah suku bunga pasar.

Keenam, persaingan dan Monopoli. Struktur ekonomi kapitalis adalah struktur bersaing. Kapitalisme menyatakan bahwa persaingan dapat menyebabkan suatu proses seleksi alam dan dengannya setiap individu dapat mencapai tingkat dalam posisi yang paling mampu untuk didudukinya. Orang yang mempunyai modal harus berada pada posisi yang lebih baik dari pada yang tidak punya modal. Dengan perkataan lain bahwa persaingan harus berada pada pihak yang kuat, yang beruntung, dengan mengorbankan silemah yang malang, sistem ekonomi kapitalis dalam persaingan berusaha untuk memonopoli. ${ }^{19}$

Kebaikan - Kebaikan Sistem Ekonomi Kapitalisme , yaitu: ${ }^{20}$ (1) Para pendukung mazhab sistem ekonomi kapitalis menyatakan bahwa kebebasan ekonomi sangat bermanfaat bagi masyarakat; (2) Persaingan bebas diantara individu akan mewujudkan tahap "produksi" dan "tingkat harga" pada tingkat yang wajar dan akan membantu mempertahankan penyesuaian yang rasional diantara kedua variabel. Persaingan akan mempertahankan tahap keuntungan dan upah pada tingkat yang sderhana dan rasional dan (3) Para ahli ekonomi kapitalis menyatakan bahwa motivasi untuk mendapatkan keuntungan merupakan tujuan yang terbaik, sebanding dengan tujuan untuk memaksimumkan. Semakin sedikit ksempatan untuk memperoleh keuntungan semakin kecil semangat untuk bekerja dan meningkatkan produksi.

\footnotetext{
${ }^{17}$ M.Dawam Raharjo, Islam dan Transformasi Sosial-Ekonomi, LSAF, Jakarta, hal. 83-84.

${ }^{18}$ M. Abdul Mannan, Op.Cit., hal. 313.

19 , Ibid., hal. 315

${ }^{20}$ Ibid, hal. 315.
} 
Sebaliknya jika kita mempertahankan motivasi mendapatkan setiap individu untuk memperoleh pendapatan sebanyak mungkin, setiap orang akan berupaya bekerja keras dengan tenaga yang maksimum serta berusaha untuk melakukan produksi maksimum. Persepsi yang dikemukakan oleh para pendukung ekonomi kapitalis tersebut di atas untuk menumbuhkan semangat dan menyadarkan kita bahwa ekonomi sudah dikuasai oleh kaum kapitalisme yang secara tidak sadar, karena dengan upaya kerja keras dengan tenaga maksimum untuk memperoleh pendapatan yang layak. Kalau tidak demikian pendapatan para pekerja akan tetap kecil dan tidak mengikat. Disamping kebaikan yang dikemukakan di atas ada kelemahan-kelemannya.

Kelemahan-kelemahan Sistem Ekonomi Kapitalis, yaitu: ${ }^{21}$ (1) Persaingan bebas yang tidak terbatas mengakibatkan banyak keburukan dalam masyarakat apabila ia mengganggu kapasitas kerja dan sistem ekonomi serta munculnya semangat persaingan diantara individu. Sebagai contoh hak individu yang tidak terbatas untuk memiliki harta mengakibatkan pengumpulan kekayaan secara berlebihan oleh beberapa individu. Kondisi ini mengakibatkan distribusi kekayaan yang tidak seimbang dalam masyarakat dan pada akhirnya akan merusak sistem perekonomian; (2) Tidak memperhatikan nilai-nilai moral seperti persaudaraan, kerja sama, saling membantu, kasih sayang dan murah hati, karena masing-masing bekerja untuk mencapai motivasi peribadi; (3) Adanya perbedaan yang radikal (jelas) antara hak-hak majikan dan pekerja. Penerima upah tidak mempunyai kesempatan yang sama dengan saingannya. Sehingga ketidak adilan ini memperdalam gap (jurang) antara yang kaya dengan yang miskin; (4) Sistem ekonomi kapitalis, di satu pihak memberikan seluruh manfaat produksi dan distribusi di bawah penguasaan para ahli, yang mengesampingkan masalah kesejahteraan masyarakat banyak dan membatasi mengalirnya kekayaan dikalangan orangorang yang tertentu saja. Di pihak lain menjamin kesejahteraan semua pekerja (yang merupakan sebagian faktor produksi) kepada beberapa orang yang hanya mementingkan diri sendiri.

Ditinjau daru norma objektif, menurut Prof. Halm untuk menilai sistem sosioekonomik ada empat kritik terhadap kapitalisme, antara lain: ${ }^{22}$ (1) distribusi kekayaan yang tidak merata; (2) kapitalisme sering dianggap kurang produktif dibanding dengan sistem kolektif yang dapat merencanakan pembangunan secra tepat; (3) kapitalisme tidak cukup kompetitif, motif laba dan perjuangan yang kompetitif bersamaan dengan teknologi modern menyebabkan kecenderungan monopoli yang melanggar falsafat kapitalisme. Dan (4) Kapitalisme tidak selalu mempertahankan tingkat kesempatan kerja yang tinggi.

\section{PEMBAHASAN}

Islam adalah agama yang ajaran-ajarannya diwahyukan Allah SWT kepada masyarakat melalui Nabi Muhammad SAW ${ }^{23}$. Islam pada hakekatnya membawa ajaranajaran yang bukan hanya mengenai satu segi saja, tetapi mengenai berbagai segi dari kehidupan manusia. al-Qur'an dan Sunnah Rasulullah SAW, merupakan sumber tuntunan hidup bagi setiap muslim untuk menapaki kehidupan fana di dunia ini dalam rangka menuju kehidupan kekal di akhirat nanti. Al-Qur'an dan Sunnah sebagai penuntun, memiliki daya jangkau dan daya atur yang universal. Artinya, meliputi segenap aspek kehidupan umat manusia dan selalu ideal untuk masa lalu, kini dan yang akan datang. Hal ini dapat dilihat dari segi teksnya yang selalu tepat untuk diimplikasikan dalam kehidupan aktual.

${ }^{21}$ M. Abdul Mannan, op.cit hal. 316

${ }^{22}$ Ibid, hal. 316

${ }^{23}$ Nasution,, Harun, Teologi Islam Aliran-Aliran Sejarah Analisa Perbandingan, UI Press, Jakarta, 1986, hal 24 
Sumber nilai dan norma dalam ajaran Islam. Pertama, al-Qur'an. Dalam faham dan keyakinan umat Islam, al-Qur'an mengandung sabda Allah yang diwahyukan kepada Nabi Muhammad SAW untuk disebarkan dan dijadikan pedoman hidup bagi umat manusia agar hidup bahagia dunia akhirat. Hadits sebagai sumber kedua dari ajaran Islam, yang mengandung ucapan, perbuatan atau persetujuan secara diam oleh Nabi Muhammad SAW.

Ajaran yang terpenting dalam Islam adalah tauhid, sebagai halnya dalam agama monoteisme atau agama tauhid lainnya, yang menjadi dasar dari segala dasar ialah pengakuan tentang adanya Tuhan Yang Maha Esa. Disamping itu menjadi dasar pula soal kerasulan, wahyu, kitab suci, soal orang yang percaya kepada ajaran yang dibawa oleh Nabi Muhammad SAW, yaitu soal mu'min dan muslim, soal orang yang tak percaya kepada ajaran-ajaran itu, yakni soal akhir hidup manusia yaitu sorga atau neraka atau sebaliknya.

Secara umum, tugas kekhalifahan manusia adalah tugas mewujudkan kemakmuran dan kesejahteraan dalam hidup dan kehidupannya (al-An'aam: 165) serta tugas pengabdian atau ibadah secara arti luas (adz-Dzaariyaat: 56) ${ }^{24}$. untuk menuniakan tugas tersebut, Allah SWT memberi manusia dua anugerah nikamat utama, yaitu manhaj al-hayat (sistem kehidupan) dan wasilah al-hayat sarana kehidupan. Manhaj al-hayat adalah segala aturan kehidupan manusia bersumber kepada Al-Qur,an dan Sunnah Rasul . aturan tersebut berbentuk keharusan melakukan atau sebalikya melakukan sesuatu, juga dalam bentuk melakukan atau sebaliknya meninggalkan sesuatu. Aturan tersebut dikenal hukum lima, yakni wajib, sunnah, mubah, makruh dan haram. Dimana peraturan tersebut menjamin keselamatan manusia baik menyangkut keselamatan agama, keselamatan diri, keselamatan akal, keselamatan harta benda maupun keselamatan nasab keturunan. Pelaksanaan Islam sebagai way of life akan melahirkan tatanan kehidupan yang baik disebut hayatan thayyibah (an-Nahl: 97) ${ }^{25}$.

Aturan aturan juga diperlukan untuk mengelola wasilah al- hayat segala sarana dan prasarana kehidupan yang diciptakan Allah SWT untuk kepentingan hidup manusia secara keseluruhan. Wasilah al-hayat ini dalam bentuk udara, air, tumbuh-tumbuhan, hewan, dan harta benda yang lain. Dalam al-Qur'an suarat al-Baqarah : 29 , yang artinya:

"Dialah Allah yang menjadikan segala yang ada di bumi untuk kamu dan Dia berkehendak (menciptakan) langit, lalu dijadika-Nya tujuh langit. Dan, Dia Maha Mengetahui segala sesuatu “. (al-Baqarah:29)

Dalam konteks ini, Islam mempunyai pandangan yang jelas mengenai harta dan kegiatan ekonomi serta bidang-bidang ilmu lainnya yang tidak luput dari kajian Islam, yang bertujuan menuntun agar manusia berada di jalan lurus (shirat al-mustaqim). ${ }^{26}$ Pandangan Islam mengenai harta dan kegiatan ekonomi: ${ }^{27}$ Pertama, pemilik mutlak terhadap segala sesuatu yang ada di muka bumi, termasuk harta benda adalah Allah SWT. kepemilikan oleh manusia hanya bersifat relatif, sebatas melaksanakan amanah mengelola dan memanfaatkan sesuai dengan ketentuan-Nya.

Kedua, status harta yang dimiliki manuasia adalah: (1) harta sebagai amanah dari Allah SWT, manusia hanya pemegang amanah karena memang manusia tidak mampu mengadakan benda dari tiada. Dari bahasa Enstin, manusia tidak mampu menciptakan energi, yang mampu dilakukan oleh manusia adalah merubah dari satu bentuk energi ke energi lain; (2) harta sebagai perhiasan hidup yang memungkinkan manusia bisa menikmatinya dengan

\footnotetext{
${ }^{24}$ Muhammad Syafii Antonio, Bank Syari'ah, dari Teori ke Praktek, Gema Insani, Jakarta, 2001, hal 7

${ }^{25}$ Muhammad Syafii Antonio, Ibid, hal 8.

${ }^{26}$ Achmad Ramzy Tadjoeddin, dkk., Berbagai Aspek Ekonomi Islam, Tiara Wacana dan P3EI UII, Yogyakarta, 1992, hal. 3.

${ }^{27}$ Muhammad Syafii Antonio, Op. Cit, hal. 10
} 
baik dan tidak berlebih-lebihan. Manusia memiliki kecenderungan yang kuat untuk memiliki, menguasai dan menikmati harta (Ali Imran:14), Al-Alaq: 6-7); (3) harta sebagai ujian keimanan (al-Afaal: 28) dan (4) harta sebagai bekal ibadah yaitu melaksanakan perintah-Nya (at-Taubah: 41, 60 Ali Imran: 133-134)

Ketiga,pemilikan harta dapat dilakukan antara lain melalui usaha (a'mal) atau mata pencaharian (ma'isyah) yang halal sesuai dengan aturan-Nya (al-Milk: 15, al-Baqarah:267, atTaubah: 105). "mencari rejeki yang halal adalah wajib setelah kewajiban yang lain" (HR. Thabrani). "Sesungguhnya Allah mencari hamba-Nya yang bekerja. Barang siapa yang bekerja keras mencari nafkah yang halal untuk keluarganya maka sama seperti mujahid di jalan Allah (HR Ahmad).

Keempat, dilarang mencari harta, berusaha atau bekerja yang dapat melupakan kematian (at-Takaatsur: 1-2, ) melupakan dzikrullah (tidak ingat kepada Allah dengan segala ketentuan-Nya) (al-Munaafiquun: 9) melupakan shalat dan zakat (an-Nuur: 37) dan memusatkan kekayaan hanya pada sekelompok orang saja (al-Hasyr: 7).

Kelima, dilarang menempuh usaha yang haram, seperti kegiatan riba (al-Baqarah: 273281), perjudian, jual beli barang yang haram (al-Maa'idah: 90-91), mencuri, merampok (alMaa'idah: 38), curang dalam takaran timbangan (al-Muthaffifiin: 1-6) melalui cara-cara yang batil dan merugikan (al-Baqarah: 188) dan melalui suap menyuap (HR Imam Ahmad).

Kegiatan ekonomi dalam pandangan Islam merupakan tuntunan kehidupan. Disamping itu juga merupakan anjuran yang memiliki dimensi ibadah. Dalam ini dapat dilihat antara lain dalam ayat-ayat berikut: " Sesungguhnya Kami telah menempatkan kamu sekalian di muka bumi dan Kami adakan bagimu di muka bumi itu (sumber) penghidupan. Amat sedikitlah kamu bersyukur”. QS.: al-“Araf: 10). Dalam ayat lain: "Dialah yang menjadikan bumi itu mudah bagimu, maka berjalanlah (mencari rejeki kehidupanlah) di segala penjurunya dan makanlah sebagian dari rejeki-Nya. Hanya kepada-Nyalah kamu (kembali setelah) dibangkitkan". (QS.: al-Mulk: 15) Dan masih banyak ayat lain yang senafas dengan ayat tersebut yang berkaitan dengan ekonomi.

Selain itu Sunnah Nabi juga banyak yang berbicara dalam konteks perekonomian umat antara lain yang dikemukakan dalam sebuah hadis (riwayat Nasa'i), "Berusahalah untuk mendapatkan perlindungan Tuhanmu dari kekafiran, kekurangan dan kehinaan". Dalam hadis lain yang diriwayatkan oleh Abdullah, Rasulullah SAW. Mengemukakan, "Berusahalah untuk memperoleh kehidupan dengan cara yang halal, merupakan suatu kewajiban sesudah kewajiban sembahyang”. ${ }^{28}$

Dari statemen yang diungkapkan al-Qur'an dan Sunnah tersebut di atas, dengan jelas menunjukkan bahwa harta (kekayaan materi) dari perspektif Islam merupakan bagian yang sangat penting dalam kehidupan kaum muslim. Dengan demikian, dapat dikatakan bahwa sesungguhnya Islam tidak menghendaki umatnya hidup dalam ketertinggalan dan keterbelakangan ekonomi, hal ini sangat relevan dengan ungkapan "Sungguh Kafakiran itu mendekati kepada kekufuran" (hadis).

Sekalipun Islam menempatkan permasalahan ekonomi ini dalam proporsi yang cukup vital, namun demikian Islam tidak menghendaki pemeluknya menjadi mesin ekonomi yang melahirkan budaya materialisme. Aktivitas ekonomi dalam pandangan Islam tidak bersifat materi saja akan tetapi lebih dari itu -"bersifat materi plus"-. Islam selalu menekankan agar setiap orang mencari nafkah dengan cara yang halal. Oleh karena itu semua sarana dalam upaya mendapatkan kekayaan secara illegal dilarang oleh Islam, karena dampaknya akan dapat membinasakan suatu bangsa. (Q.S.: al-Nisa' : 29). Rakus terhadap kekayaan dan sikap mementingkan materi belaka sangat dicela, untuk itu baik al-Qur'an maupun Hadis dalam

${ }^{28}$ Muhammad Nejatullah Siddiqi, Kegiatan Ekonomi Dalam Islam, Bumui Aksara, Jakarta, 1991, hal. 12 - 13 . 
berbagai ayat amat banyak memberikan rambu-rambu, antara lain: "Berpalinglah (wahai Muhammad) dari orang-orang yang berpaling dari peringatan Kami dan hanya mendahulukan kepentingan duniawi saja". (QS.: al-Najm: 29) "Siapa yang menghendaki (melalui usahanya) keuntungan duniawi saja, maka Kami berikan keuntungan itu kepadanya, dan dia tidak akan mendapatkan apapun di akhirat kelak". (QS.: al-Syurah: 20) "Adapun orang yang kafir, memuaskan nafsunya dengan kenikmatan duniawi, mereka makan seperti binatang, kelak nerakalah tampat tinggal mereka". (QS.Muhammad: 12)

Dalam hadis yang diriwayatkan oleh al-Bukhari sebagimana dikutip oleh Muhammad Najetullah al-Siddiqi, dikemukakan: "Demi Allah aku tidak mengkhawatirkan kemiskinanmu, tetapi lebih mengkhawatirkan kemewahan duniawi yang kamu peroleh. Lalu kamu saling berlomba mengadakan persaingan diantara sesama kamu sebagaimana telah dilakukan oleh orang-orang sebelum kamu dan telah diberikan kemewahan juga. Hal itu akan membinasakan kamu sebagimana telah membinasakan mereka".

Bersandarkan kepada uraian yang dikemukakan di atas, aktivitas ekonomi dalam pandangan Islam pada hakikatnya bertujuan untuk: (1) Memenuhi kebutuhan hidup seseorang scara sederhana; (2) Memenuhi kebutuhan keluarga; (3) Memenuhi kebutuhan jangka panjang; (4) Menyediakan kebutuhan keluarga yang ditinggalkan.dan (5) Memberikan bantuan sosial dan sumbangan menurut jalan Allah ${ }^{29}$

Dalam rangka pencapaian itulah Islam memberikan panduan dan aturan tentang bentuk kebebasan aktivitas manusia dalam memperoleh kekayaan. Konsep Islam amat jelas. Manusia dilahirkan merdeka, setiap individu berhak menggunkan kemerdekaannya sepanjang berada pada norma-norma Islami. Dengan kata lain sepanjang kebebasan tersebut dapat dipertanggung jawabkan, baik secara sosial maupun dihadapan Allah.

Islam mengakui pandangan universal bahwa kebebasan individu bersinggungan atau bahkan dibatasi oleh kebebasan individu orang lain. Menyangkut masalah individu hak individu dalam kaitannya dengan masyarakat, para sarjana muslim bersepakat pada prinsipprinsip berikut ini; (1) kepentingan masyarakat yang lebih luas harus didahulukan dari kepentingan individu; (2) Melepas kesulitan harus diprioritaskan dibanding memberi manfaat, meskipun keduanya sama-sama merupakan tujuan syari'ah; (3) Keugian yang lebih besar tidak dapat diterima untuk menghilangkan yang lebih kecil. Manfaat yang lebih besar tidak dapat dikorbankan untuk manfaat yang lebih kecil. Sebaliknya, bahaya yang lebih kecil harus dapat diterima/diambil untuk menghindarkan bahaya yang lebih besar, sedangkan manfaat yang lebih kecil dapat dikorbankan untuk mendapatkan manfaat yang lebih besar.

Kebebasan dalam kerangka etika Islam diakui selama tidak bertentangan dengan kepentingan sosial yang lebih besar selama atau sepanjang individu itu tidakmelangkahi hakhak orang lain. Berbeda dengan Islam, dalam pandangan humanisme, manusia adalah ukuran dari segala hal, pusat dari arti penting (significanse) dan wadah dari segala kebijakan. ${ }^{30}$ Karena manusia sebagai wadah dari kebijakan, maka setiap aktifitas tidak terlepas dari sifat kemanusiaan. Islam menempatkan kemanusiaan sebagai sekunder dari nilai tauhid, konsep ketuhanan Yang Maha Esa. Dalam sistem ekonomi hendaknya tidak lepas dari nilai-nilai kemanusiaan yang tidak mementingkan kepentingan diri sendiri, sehingga tercipta ekonomi masyarakat yang merata, aman dan makmur. Munculnya sistem ekonomi yang digunakan oleh pelaku ekonomi, pada dasarnya berangkat dari rasa kesadaran pada diri masing-masing apakah mementingkan diri sendiri atau peduli kepada nasib orang lain. Ekonomi kapitalis yang mementingkan diri sendiri dan ini sangat berbeda dengan ekonomi Islam. Sebagai ilustrasi perbandingan antara ekonomi Islam dengan ekonomi Kapitalis (non Islam) dapat dilihat pada gambar 1

\footnotetext{
${ }^{29}$ Ibid., hal. 15

${ }^{30}$ M.Dawam Raharjo, Op. Cit., hal. 51
} 


\begin{tabular}{|c|c|}
\hline Sistem Ekonomi Islam & Sistem Ekonomi Kapitalis \\
\hline$\downarrow$ & $\downarrow$ \\
\hline Manusia (Sosial namun Religius & Manusia (sosial \\
\hline$\downarrow$ & $\downarrow$ \\
\hline \begin{tabular}{r|r} 
Kebutuhan-kebutu- \\
han tidak terbatas
\end{tabular} & $\begin{array}{l}\text { Kebutuhan-kebutu- } \\
\text { han tidak terbatas }\end{array}$ \\
\hline$\downarrow$ & $\downarrow$ \\
\hline Masalah-masalah Ekonomi & Masalah-masalah Ekonomi \\
\hline$\downarrow$ & $\downarrow$ \\
\hline $\begin{array}{l}\text { Pilihan di antara alternatif } \\
\text { (dituntun oleh nilai Islam) }\end{array}$ & $\begin{array}{l}\text { Pilihan di antara alternatif } \\
\text { (dituntun oleh kepentingan individu) }\end{array}$ \\
\hline$\downarrow$ & $\downarrow$ \\
\hline $\begin{array}{l}\text { Pertukaran terpadu dan transfer satu } \\
\text { arah (dituntun oleh etika Islami, } \\
\text { kekuatan pasar dan kekuatan bukan } \\
\text { pasar) }\end{array}$ & Pertukaran dituntun kekuatan pasar. \\
\hline
\end{tabular}

Sumber : M, Abdul Mannan, 1995 hal. 20

Gambar 1 Perbandingan antar Ekonomi Islam dan Kapitalisme

Dalam ilmu ekonomi Islam tidak hanya mempelajari individu dan sosial melainkan juga manusia dengan bakat religius manusia. Hal ini disebabkan banyaknya kebutuhan dan kurangnya sarana, dari sini muncullah masalah ekonomi. Masalah ini pada dasarnya sama dalam semua sistem ekonomi baik ekonomi Islam maupun ekonomi yang lainnya. Namun kemudian muncul perbedaan dalam pemilihan sistem pelaksanaan apakah dikendalikan oleh nilai Islam atau dikuasai oleh kepentingan diri sendiri.

Islam dalam memandang masalah ekonomi berbeda dari sudut pandang kapitalis. Islam memberikan kebebasan serta hak milik ${ }^{31}$ kepada individu dan mengelola usaha secara peribadi, akan tetapi tanpa merusak ekonomi masyarakat. Pemilikan pribadi dalam pandangan Islam tidaklah bersifat mutlak/absolut (bebas tanpa kendali dan batas). Sebab di dalam

${ }^{31}$ Istilah milik berasal dari bahasa Arab yaitu "milk". Dalam kamus al-Munjid dikemukakan bahwa kata-kata yang bersamaan artinya dengan milk (yang berakar dari kata kerja malaka) adalah "malkan", "milkan', "malakatan", "mamlikatan" dan "mamlukatan". Milik dalam lughah (arti bahasa) dapat diartikan "Memiliki sesuatu dan dapat bertindak secara bebas terhadapnya". (Hasbi al-Siddiqi, Pengantar Fiqh Mu'amalah, Bulan Bintang, Jakarta, 1998, hal. 8). Sedangkan menurut istilah dapat didefinisikan, "suatu ikhtisas yang menghalangi yang lain, menurut syaria't, yang membenarkan pemilik ikhtisas itu bertindak terhadap barang miliknya sekehendaknya, kecuali ada penghalang. (Ibid.). Kata menghalangi dalam definisi di atas maksudnya adalah sesuatu yang mencegah orang yang bukan pemilik ssuatu barang untuk mempergunakan/memanfaatkan dan bertindak tanpa persetujuan lebih dahulu dari pemiliknya. Sedangkan pengertian penghalang adalah sesuatu ketentuan yang mencegah pemilik untuk bertindak terhadap harta miliknya 
berbagai ketentuan hukum dijumpai beberapa batasan dan kendali yang tidak boleh dikesampingkan oleh seorang muslim dalam pengelolaan dan pemanfaatan harta miliknya. Untuk itu dapat disebutkan prinsip dasarnya yaitu: (1) pada hakikatnya individu adalah wakil masyarakat dan (2) harta benda tidak boleh hanya berada ditangan pribadi (sekelompok) anggota masyarakat.

Prinsip tersebut menggambarkan Sistem ekonomi Islam merupakan sistem yang adil dan seksama serta berupaya menjamin kekayaan tidak terkumpul hanya pada satu kelompok saja, tetapi tersebar keseluruh masyarakat. Hal ini sebagaimana diungkapkan dalam alQur'an: "Supaya harta itu jangan hanya beredar di antara golongan kaya saja dikalangan kamu” (al-Hasyar: 7). Prinsip ini dimaksudkan untuk menjaga keseimbangan dan kestabilan dalam masyarakat. Seandainya harta itu hanya berada ditangan pribadi (monopili kelompok) tentu, anugerah Allah tersebut hanya berada di tangan segelintir orang. Dalam konteks kekinian, hal tersebut dapat diambil ilustrasi bahwa sikap mental ologopoli, monopoli, kartel dan yang sejenis dengannya merupakan sikap mental pengingkaran nurani kemanusiaan dan jelas-jelas menyimpang dari aturan Islam.

\section{PENUTUP}

Globalisasi dunia yang sering-sering disebut belakangan ini adalah merupakan dampak langsung dari keberhasilan revolusi teknologi komunikasi, setelah didahului oleh dua revolusi dalam kebudayaan manusia, yaitu revolusi pertanian dan revolusi industri. Untuk era sekarang ini, ketiga jenis revolusi tersebut telah menyatu menjadi satu menyongsong era baru yang populer dengan istilah era "pasar bebas" yang sudah hadir dihadapan kita yang dampaknya jauh akan lebih hebat lagi.

Dalam era globalisasi dan pasar bebas hampir semua sendi-sendi kehidupan manusia telah berubah. Kehidupan individu, hubungan antar anggota keluarga, kehidupan masyarakat, berbangsa dan bernegara. Yang tidak berubah hanyalah pengertian bahwa dunia adalah berubah. Sebagai konsekwensi logis dari kondisi tersebut, masyarakat dituntut untuk mempersiapkan diri dan membekali diri untuk mampu berkompetisi dalam kancah persaingan yang cukup ketat. Oleh karena itu Islam (kaum muslimin) dihadapkan kepada berbagai tantangan yang semakin kompleks dan rumit, ia harus mampu menyiapkan diri dan warga masyarakat secara mental maupun fisik guna menyongsong era kehidupan global. Dalam konteks ini, Islam harus lebih agresif dan selektif dalam merespons setiap perubahan yang akan terjadi, karena era pasar bebas adalah suatu era yang cukup kondusip dan subur untuk tumbuh dan berkembangnya sistem kapitalisme. Sehingga tidak terlalu keliru kalau sebahagian pemikir maramalkan bahwa era pasar bebas sangat identik dengan era new kapitalisme (munculnya era kapitalisme baru dunia). Padahal dari pembahasan di atas, secara jelas dapat disimpulkan bahwa sistem kapitalisme jelas-jelas menyimpang dan bertentangan dengan prinsip-prinsip dasar tuntunan Islam. Disinilah barangkali moment yang cukup penting kahadiran Islam sebagai sebuah sistem alternatif yang dapat menjawab tantangan masa depan.

Melihat kenyataan krisis ekonomi yang terjadi di berbagai negara, termasuk Indonesia yaang belum kunjung usai telah memporak porandakan sendi-sendi kehidupan sosial. Hal ini menunjukkan beluam mampunya "ekonomi pasar" atau kapitalisme yang di ilhami oleh teori invisible hand Adam Smith, untuk mengatasi masalah-masalah ekonomi (pengangguran, inflasi, distribusi pendapatan tidak merata, kemiskinan). Berbagai cara telah ditempuh, baik dengan kebijakan moneter maupun fiskal, namun persolan ekonomi tetap saja muncul dan menghantui banyak negara dimana-mana. Dimana letak kesalahan ekonomi pasar atau 
kapitalis yang sebagian besar dianut oleh banyak negara termasuk Indonesia, bukankah resep pembangunan ekonomi Adam Smith telah dilaksanakan. Dunia sedang memerlukan ekonomi Ilahiah, ekonomi yang konsepnya dilandasi oleh Al-Qur'an dan Hadits, ekonomi yang dikembangkan dengan akhlak yang mulia. Mungkin inilah yang sedang ditunggu oleh umat manusia, Allah subhanahu wa ta'ala rupanya Allah sedang menguji semua manusia dengan derita ekonomi yang berkepanjangan agar mereka kembali ke jalan-Nya yang lurus, insyaaallah. 


\section{DAFTAR PUSTAKA}

Abdul Mannan, M,(1995), Teori dan Praktek Ekonomi Islam, Terj. M.Nastangin, Dana Bakti Wakaf, Yogyakarta.

Achmad Ramzy Tadjoeddin, dkk., (1992), Berbagai Aspek Ekonomi Islam, Tiara Wacana dan P3EI UII, Yogyakarta.

Alfred W. Stonier, Douglass C. Hague, (1984), Teori Ekonomi, Ghalia Indonesia, Jakarta.

Daniel R. Fusfeld, (1972), The Age of the Economist, Ideas that Shape the Way we Live, Pyramid Publication, New York.

Dawam Raharjo, M , (1986), Islam dan Transformasi Sosial-Ekonomi, LSAF, Jakarta.

Hasbi al-Siddiqi, (1998), Pengantar Fiqh Mu'amalah, Bulan Bintang, Jakarta.

Kaelany, (1992), Islam dan Aspek-Aspek Kemasyarakatan, Bumi Aksara, Jakarta.

Monzer Kahf, (1986), Ekonomi Islam (Telaah Analitik Terhadap Fungsi Sistem Ekonomi Islam), Pustaka Pelajar, Yogyakarta.

Max Weber, (1989), Kapitalisme, Demokrasi dan Agama, Terj. Hartono H., Tiara Wacana Yogyakarta.

Muhammad Syafii Antonio, (2001), Bank Syari'ah, dari Teori ke Praktek, Gema Insani, Jakarta.

Muhammad Nejatullah Siddiqi, (1991), Kegiatan Ekonomi Dalam Islam, Bumui Aksara, Jakarta.

Nasution,, Harun, (1986), Teologi Islam Aliran-Aliran Sejarah Analisa Perbandingan, UI Press, Jakarta.

Samuelson, Paul A, (1973), Economics, Ninth Edition, Mc Graw Hill Kogakusha, Ltd. Tokyo.

Suherman Rosidi, (1995), Pengantar Teori Ekonomi, PT. Raja Grafindo Persada, Jakarta.

Suwardi K. Lubis , (1995), Hukum Ekonomi Islam, Sinar Grafika, Jakarta..

Winardi, (1986), Kapitalisme Versus Sosialisme, Suatu Analisis Ekonomi Teoritis, Remadja Rosdakarya, Bandung 
